Western University

Scholarship@Western

Aboriginal Policy Research Consortium International (APRCi)

6-2009

\title{
Australian Aboriginal Ethnometeorology and Seasonal Calendars
}

Philip A. Clarke

Follow this and additional works at: https://ir.lib.uwo.ca/aprci

Part of the Cultural History Commons, and the Social and Cultural Anthropology Commons

Citation of this paper:

Clarke, Philip A., "Australian Aboriginal Ethnometeorology and Seasonal Calendars" (2009). Aboriginal Policy Research Consortium International (APRCi). 418.

https://ir.lib.uwo.ca/aprci/418 
This article was downloaded by: [University of Western Ontario]

On: 10 December 2012, At: 08:20

Publisher: Routledge

Informa Ltd Registered in England and Wales Registered Number: 1072954 Registered

office: Mortimer House, 37-41 Mortimer Street, London W1T 3J H, UK

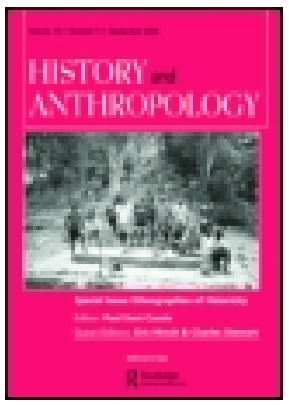

\section{History and Anthropology}

Publication details, including instructions for authors and subscription information:

http:// www. tandfonline.com/loi/ghan20

\section{Australian Aboriginal Ethnometeorology and Seasonal Calendars}

Philip A. Clarke

Version of record first published: 21 Apr 2009.

To cite this article: Philip A. Clarke (2009): Australian Aboriginal Ethnometeorology and Seasonal Calendars, History and Anthropology, 20:2, 79-106

To link to this article: http:// dx.doi.org/ 10.1080/ 02757200902867677

\section{PLEASE SCROLL DOWN FOR ARTICLE}

Full terms and conditions of use: http://www.tandfonline.com/page/terms-andconditions

This article may be used for research, teaching, and private study purposes. Any substantial or systematic reproduction, redistribution, reselling, loan, sub-licensing, systematic supply, or distribution in any form to anyone is expressly forbidden.

The publisher does not give any warranty express or implied or make any representation that the contents will be complete or accurate or up to date. The accuracy of any instructions, formulae, and drug doses should be independently verified with primary sources. The publisher shall not be liable for any loss, actions, claims, proceedings, demand, or costs or damages whatsoever or howsoever caused arising directly or indirectly in connection with or arising out of the use of this material. 


\title{
Australian Aboriginal Ethnometeorology and Seasonal Calendars
}

\author{
Philip A. Clarke*
}

This paper uses a cultural anthropological approach to investigate an indigenous Australian perspective on atmospheric phenomena and seasons, using data gained from historical records and ethnographic fieldwork. Aboriginal people believe that the forces driving the weather are derived from Creation Ancestors and spirits, asserting that short term changes are produced through ritual. By recognizing signals such as wind direction, rainfall, temperature change, celestial movements, animal behaviour and the flowering of plants, Aboriginal people are able to divide the year into seasons. Indigenous calendars vary widely across Australia and reflect annual changes within Aboriginal lifestyles.

Keywords: Ethnometeorology; Weather; Seasons; Calendars; Time; Cosmology

\section{Introduction}

When the British settled Australia in 1788, it was a continent of hunter-gatherers, with horticulture restricted to the Torres Straits area of northern Queensland (Lawrence 1968, Lourandos 1997, Mulvaney \& Kamminga 1999). On a drought-prone continent with harsh climatic extremes, Australian hunter-gatherers maintained their mobility to maximize the seasonal availability of food, water, medicine, shelter and artefactmaking materials. Aboriginal people drew upon their understanding of the calendar when deliberately burning their country (Bradley 1995, Clarke 2007, Pyne 1991). The way of life for Aboriginal people demanded a detailed knowledge of the relationships between weather and the landscape, enabling them to observe and forecast its constant changes (Jones 1985b, Rose 1987, 1997, Simpson 1997, Stevenson 1985). Historian

\footnotetext{
*Philip A. Clarke, Anthropology Department, Science Division, South Australian Museum, North Terrace, Adelaide, South Australia, 5000, Australia. Email: Clarke.Philip2@saugov.sa.gov.au
} 
Geoffrey Blainey referred to the reasoning behind their nomadic existence as "the logic of unending travel" (Blainey 1976).

In Australian English, the corpus of beliefs underpinning Aboriginal religion is referred to as the "Dreaming" (Arthur 1996, Rose 1987, Sutton 1988a). Fundamental to this concept is the Aboriginal belief of a past Creation when Ancestors performed heroic deeds, moulded and enhanced the land, and laid down custom. The main Dreaming beings are the spiritual Ancestors of the present day Aboriginal community. They are often manifested as animals and birds, but are also plants, and cosmological and atmospheric phenomena. Aboriginal people collectively perceive the Dreaming as the Ancestors, the practices they introduced, and the tangible objects and places that they left behind in their country.

The Dreaming gives order to the Aboriginal world, acknowledging a common origin for people and the environment. Among the indigenous residents of the Yarralin community on Victoria River Downs Station in the Northern Territory, Rose recorded that the "Sun and rain (Rainbow Snake) were walking in human form during the Dreaming. At that time they tested laws and ultimately established the conditions [that is, the seasons] of their present existence and of their relationship" (Rose 1987). Since the end of the Creation period, the Sun's heat makes the plants and animals grow, while rain, symbolically the Rainbow Snake, cools and washes the land. Different coloured rains are organized according to matrilineally defined groups of people (Rose 1997). Many present day Aboriginal people still consider their Dreaming knowledge of immense importance for their understanding of the world.

While Western style history serves to highlight the process of change, in Aboriginal worldviews it is the continuity and permanence of all things that is stressed. Myers commented upon the traditions of the Pintupi people in the Western Desert, and stated that "the concept of The Dreaming organizes experience so that it appears to be continuous and permanent. For the Pintupi, the dynamic, processual aspect of history seems to exist as one of the discovering, uncovering, or even re-enacting elements of The Dreaming" (Myers 1986). Sutton considered that there are major similarities between traditional Australian Aboriginal approaches to myth and post-European indigenous understandings of history, as they both build cultural identity and are referenced to events and the landscape (Sutton 1988b). In terms of differences, he remarked "They have divergent approaches to both absolute time and relative sequencing".

Across the world, hunter-gather perceptions of time have often been described as cyclical and as existing in the absence of an abstract concept (James \& Mills 2005, Stanner 1953 [1979]). In Aboriginal Australia, Dreaming traditions are based upon a notion of a sacred and heroic period in a remote past, while utilizing a concept of time which makes it part of the present (Berndt \& Berndt 1989, Gell 1992). Stanner (1953 [1979]) described this as "everywhen", and stated that Aboriginal "interest lies in the cycles rather than the continuum [of time]". For Western Desert hunter-gatherers, this is demonstrated by the use of recurring generation-classes in their kinship, the perception of which is described as "social time" (Lauer 1981). In the context of Australian Aboriginal views of the universe, this is manifested as short kinship lineages, combined with a perception of the Dreaming as being part of a recent past. 
Swain (1993) described Aboriginal experience of time in terms of the interplay between "Abiding Events" of the Dreaming and "rhythmed events", which "did not allow time ontological status. It was neither measured nor numbered, and hence their world was governed instead by the qualitative values of the enduring place". While for pre-European Aboriginal people linear changes were masked, their religious life was not static and immutable (Kolig 1984 [1981]). Aboriginal ceremonial life was dominated by the need to maintain religious cycles, but allowed for high cultural mobility along extensive communication networks.

In Western European thought, change and time is dealt with as both unidirectional and in cycles. Allen stated that "Historical sciences, such as archaeology, create long sequences where history is directional and cumulative, while ecology stresses synchronous and cyclical processes, such as tidal or seasonal change" (Allen 1997). This paper derives information from diverse data sources, such as historical records and ethnographic reports. It concerns the manner in which Aboriginal hunter-gatherers perceived the seasonal cycles of the landscape with reference to their Dreaming "history".

\section{Ethnometeorology}

Simpson stated that it was the aim of ethnometeorology to study "a people's observations of the weather, what they perceive to be the causes of the weather and, more generally, the place of weather in the life and belief system of a society" (Simpson 1997). This field fits well alongside other ethnosciences, such as ethnobotany and ethnozoology, as it concerns the description of an indigenous classification of natural phenomena, and because from a cultural insider's perspective it studies how this is incorporated into knowledge systems. Of the ethnosciences, ethnometeorology has not received as much attention from European scholars, because plants and animals are more easily observed within short periods, than is the case for weather, which is highly seasonal. The scholars' neglect of ethnometeorological studies is exacerbated by difficulties for researchers in making clear distinctions between verifiable observations of weather from explanations derived solely from mythological beliefs and traditions.

\section{The Sources}

From many parts of Australia, particularly the temperate region where European colonization was earliest and most intense, the available data on hunter-gatherer perception and use of the environment is mainly historical (Clarke 2003, 2007). Settlers and colonial officials in the nineteenth and early twentieth century, such as Peter Beveridge, James Dawson, Alfred W. Howitt, Robert H. Mathews, Peter MacPherson, Edward Palmer, George A. Robinson and William E. Stanbridge, collected much anecdotal data from Aboriginal groups under the pressure of European settlement. Missionaries, such as Johann G. Reuther, Clamor W. Schürmann, A. C. Stone, George Taplin and Christian G. Teichelmann, were more systematic in their recordings of indigenous cultures, although they operated prior to the establishment of Australian academic anthropology. 
Through the twentieth century, scholars from several disciplines compiled Aboriginal ethnographic data that is relevant to ethnometeorological research in remote areas of tropical and arid Australia. The anthropologists among them include Daisy M. Bates, Ronald M. Berndt, Catherine H. Berndt, John J. Bradley, Deborah Bird Rose, Alfred R. Brown (later A. R. Radcliffe-Brown), Athol Chase, Stephen Davis, Adolphus P. Elkin, Ursula H. McConnel, Fred R. Myers, William E. H. Stanner and W. Lloyd Warner. Rhys M. Jones and Betty Meehan worked on Aboriginal calendars as archaeologists, while Ronald Rose was interested in "magic" from a psychiatric perspective. Examples of linguists who recorded Aboriginal meteorological beliefs are John Henderson, Luise A. Hercus, David Nash, Jane Simpson and Dorothy Tunbridge. Other relevant researchers are geographer Richard M. Baker, astronomer Raymond D. Haynes, naturalist Alan Reid and historian Tony Swain. Scholars with interests in museum ethnographic collections, such as Frederick D. McCarthy, Charles P. Mountford, Walter E. Roth, Peter Sutton, Luke Taylor, Donald F. Thomson, Norman B. Tindale and I, have utilized meteorological data as a means of interpreting indigenous relationships to the environment.

\section{Ancestors and Spirits as Weather-Makers}

While European meteorologists perceive specific aspects of the weather as having independent causes, Aboriginal people believe that all natural phenomena, such as rain, fire and wind, are integrally connected. Simpson stated that Warumungu people in the Northern Territory consider that "wind blows fire, fire creates clouds which let fall rain, an event often heralded by wind" (Simpson 1997). This connectedness is explained in Aboriginal mythology. The Aboriginal perception in northeast Arnhem Land is that the Wet and Dry Season cycle is driven by the mythological Wawilak Python and linked to spiritual Ancestors. Warner claimed "The Murngin [Yolngu people] definitely associate the Wawilak python with the weather and seasonal change. The climatic ideas which surround the python are not latent but conscious and manifest in Murngin thinking” (Warner 1937 [1964]). In Aboriginal Australia, knowledge of the weather is enshrined in myth and expressed in song.

Aboriginal people explain a wide range of atmospheric phenomena in terms of the actions of Dreaming Ancestors (Clarke 2003). Ngaatjatjarra people in central Western Australia believe that cold frosty mornings are produced by their Nyinnga (Njenga) Ancestor (Tindale 1972). It was a tradition of the Wiradjuri people in eastern inland New South Wales that a mirage was smoke made from the fires of Ancestors, who were cooking their game out on the hot arid plains (Mathews 1904). The Wongaibon people, who live south of Bourke in central New South Wales, called mirages kullugu-kulli, which reportedly meant "shingleback-lizard water" (Mathews 1904). They believed that this magical water supported the shingleback ( $k u l l u)$, which typically lives far out on the arid plains away from surface water. In Aboriginal Dreaming beliefs of western Victoria, Ancestor Gartuk caught powerful storms in bags, unleashing them later upon others (Mathews 1904). 
It is Aboriginal tradition that extreme inclement weather conditions are associated with calamities caused by sorcery or through the breaking of religious protocols. Aboriginal people living around Lake Boga in central northern Victoria believed many of their number had once died because of "poison-fog" in low-lying areas, although missionaries blamed smallpox (Stone 1911). Aboriginal people had prohibitions to prevent unfavourable weather from occurring. In southeastern Australia, it was believed if certain species of frog and toad were killed that heavy rains would come (Frazer 1911, Krappe 1940). It was thought that rain could also be made inadvertently. At Bloomfield River in northern Queensland, there was a prohibition against staring at the Moon, as this was believed to result in heavy rain (Roth 1903).

\section{Sun Ancestor}

The Sun Ancestor has a prominent position in Aboriginal mythology (Clarke 1997, Johnson 1998). To account for seasonal differences between the strength of sunlight, some Aboriginal groups believed that it was produced by two different beings. Roth claimed that at Cape Bedford in northern Queensland, Aboriginal people "can, of course, see the sun starting, but at night she always circles round by the south. There are really two suns, two sisters: in the cold season it is the elder one who visits them, and in the hot season it is the younger" (Roth 1903). Aboriginal people in riverine districts of central Victoria and south central New South Wales considered the Sun to be a fire made by male Supreme Ancestors, like Ngondenont and Baiame (Beveridge 1884, Haynes 1992). In this region, the warmth of the day was equated with the strength of the Ancestor's fire and how much fuel was left to burn. A tradition of the Tangani people living along the Coorong in southern South Australia is that the Sun was in earlier times much brighter. Here, Tindale recorded the Sun as a woman, and:

a being who, in ancient times, climbed into the heavens where she carried firesticks; but these firesticks did little for people on earth in keeping them from being cold. The light from her firesticks was too bright. Another being still on earth, named Nure:le, magically forced her to be less vigorous in waving her firesticks, instead of affording much bright light there was a greater amount of red glow. Thus people could remain warm (Tindale 1983).

This belief related to an Aboriginal observation that for maximum heat their campfires needed more red coals and less bright flame.

In Aboriginal Australia, the Sun's east-west movement across the sky was a major influence upon the system of orientation (Lewis 1976, Nash 1992, Tindale 1974). Meteorological traditions were important too, by referencing the prevailing directions of the seasonal weather, particularly with the northern and southern cardinal points. Stone's published vocabulary from the Lake Boga district of central northern Victoria supports this generalization. Here, north was "barrewill (where the hot winds come from)", south as "boiecalling darn (where the frost winds come from)", east was "worwalling gnowie (where sun rises)", and west known as "purticalling gnowie (where sun sets)" (Stone 1911). 


\section{Rainbow Serpents of the Tropics}

In northern Australia, Rainbow Serpents are associated with the fertility brought to the country by monsoonal rains (Berndt \& Berndt 1989, Isaacs 1980, Merlan 1998, Rose 1987, 1997). These Ancestral spirits are generally perceived as large, to be living in deep and permanent water bodies, and to take the form of rainbows. Rainbow Serpents are also variously described as Giant Snakes or Pythons, and in a variety of contexts; as totemic Ancestor, an initiation spirit, and as rainmakers. Serpents are believed to swallow humans, particularly strangers approaching their spirit home without observing the correct ritual protocols.

In the eastern Kimberley, Rainbow Serpents are called Ungud or Lumuru (Crawford 1968). They appear as a rainbow in the sky to signal the end of a shower, but are also seen as floating logs or sea whirlpools, and always associated with water. The Rainbow Serpent image appears prominently in Kimberley rock paintings. In western Arnhem Land, Rainbow Serpents are known as Almudj, and they are responsible for bringing on the Wet Season rains and for sending the human conception spirits to the waterholes (Chaloupka 1993). In this region they are generally believed to reside in pools under waterfalls. Rainbow Serpents are the main characters in the Ubarr, Marrayin and Kunapipi ceremonies, and are a common motif in the rock paintings. In the Djungguwan ceremony of western Arnhem Land, a Rainbow Serpent, in the form of a giant Python, swallows the ancestral Wawalag Sisters (McCarthy 1953, Taylor 1996). ${ }^{1}$ The rainbow is seen as either his house or drone pipe (didjeridu), while thunder is his voice and the lightning his tongue.

The Gidjingali people in central Arnhem Land have a tradition that the spirit Modj, who takes the form of a Rainbow Serpent, is responsible for the damaging storms that cause coastal inundation (Jones \& Meehan 1997). Modj is considered to live in the deepest parts of the river. Arnhem Land people believe that "medicine men" are able to stop floods by diving into the water to catch Rainbow Serpents (as Pythons) and to send then back to their proper underwater home (McCarthy 1953). All permanent pools with tropical water lilies are considered potential homes for these Spirit Ancestors. In northeast Arnhem Land, Yolngu people reason that monsoonal thunder is caused by large Snake Ancestors talking, while lightning comes from a huge Python Ancestor disturbed from his home (Davis 1997).

In some northern Aboriginal languages, such as that spoken by the Kayardilt of Bentinck Island in the Gulf of Carpentaria, Rainbow Serpents and rainbows are referred to by the same word (Ngakulmungan Kangka Leman 1997 cited in Simpson 1997). Among the Wik people from northwest Cape York Peninsula in Queensland, there is the tradition of a large Carpet Snake Ancestor, Oyangorpan (Oingorpan), who lives underground (McConnel 1930, Sutton personal communication). He is said to eat strangers and have a voice heard as thunder. In the mythology of the Kuku-Yalanji people of northern Queensland, a pair of storm-birds, who live in the rocks surrounding the Rainbow Serpents' dwelling, bring on the monsoon when the female of the pair calls to thunder, the Serpent's son (McCarthy 1953). If anyone killed these birds, it was believed that floods would swamp the land. 


\section{Desert Water Snakes}

Snakes are common characters in desert Dreaming narratives. Mountford claimed that "the snake is almost always connected with water, the majority of the [desert] rivers, creeks and water-courses having been created by his agency, while almost every permanent waterhole is the home of one or the other of the serpent forebears" (Mountford 1937). There are many written accounts from the Western Desert of Snake Ancestors associated with water, such as the Wanambi ("Mythical Snake") at Uluru (Ayers Rock) in the Northern Territory (Mountford 1965), the Wanampi Kutjara ("Two Watersnakes") from the Warburton district in central Western Australia (Gould 1969, Tindale 1935) and the "Rainbow Serpent" at Labbi Labbi near Lake Hazlett in central Western Australia (Thomson 1975). The Water Snakes of the desert and the Rainbow Serpents of the tropics share many characteristics.

Wanambi Snake Ancestors are only associated with permanent desert waterholes (Buchler \& Maddock 1978, Tindale 1972). During times of hardship in the northern deserts of Western Australia, the Walmadjeri people visited permanent waterholes and appealed to the Wanambi to release more water (Tindale 1974). Berndt described " $g a b i$ routes" (water-hole tracks) that linked Water Snake sites into Dreaming tracks, which crisscrossed the Western Desert (Berndt \& Berndt 1942). Desert dwellers followed these routes during the passage of seasons.

I noted during Western Desert fieldwork commencing in the early 1990s among the Anangu Pitjantjatjara people, that the Wanambi Dreaming track incorporated strings of rock holes in the Everard Ranges of northwest South Australia. ${ }^{2}$ Here, the Wanambi is depicted in rock paintings and his body associated with particular granitic landforms that have snake-like appearances. During my Northern Goldfields fieldwork in the early 2000s, Wonggai people connected their main water sources to the shared mythology of Tjinkunya the Dragonfly and Tjila the Water Snake (see Liberman 1980). They explained that in the Creation period, the Tjila had ejaculated or vomited up certain salt lakes, while he had made many of the ngamma holes or small rock reservoirs containing drinking water by pushing through the limestone.

\section{Serpents of the Temperate South}

The Wiradjuri people of eastern inland New South Wales believed in serpent-like spirits, the Wawi, who made their homes in the banks of deep waterholes (Mathews 1904). Here, Aboriginal “doctors" located their dens by tracing rainbows back during thundershowers. The Wawi, and other Serpent beings analogous to the northern Rainbow Serpent, were involved in the Bora initiation ceremonies of eastern New South Wales, and were said to live in permanent lagoons and waterholes (Brown 1930). In the New England Tableland of northeast New South Wales, Serpent spirits were closely associated with waterfalls, possibly, as Brown suggested, because this is where rainbows are most often seen. For Aboriginal people in the Lake Tyrrell district of central northern Victoria, two giant Snake Ancestors, the Mindii, were credited with making the Murray River and were believed to still reside in the Skyworld (Smyth 1878). 
The Aboriginal people of the Adelaide Plains in South Australia considered that the dark spots in the Milky Way were water lagoons where lived the Yura Serpents (Clarke 1997, Teichelmann 1841). Adelaide people claimed that the monster Yura was vicious and would swallow people who did not hide from him. When he appeared, an abundance of water was created. The Akurra (Akaru) are huge mythical Water Snakes in Adnyamathanha tradition of the Flinders Ranges in South Australia (Berndt \& Vogelsang 1941, Tunbridge 1988). The Akurra is sometimes considered to be a single being, although able to be in many places at once. Adnyamathanha people believe that the pearl shell pendants worn by their first stage male initiates were "ticks" that the "doctor man" had removed from the Akurra's neck.

Recorded Aboriginal mythology from southwest Western Australia contains many accounts of Waugal Serpent Ancestors (Churches 1992, Isaacs 1992). Bates recorded that the "Waw-gal [Waugal] ... controlled earth, fire, and water: it caused or prevented sickness and death; it made the most important food and totem laws; and was the punisher-in-chief for any breach of these laws. ... there was a local waw-gal 'shrine,' [that] might be but a pool, hill, rock, tree, cave" (Bates 1925 [1992]). From her description, the Waugal had control of the weather. Bates linked this Serpent mythology from the temperate region to that from the desert and tropical regions further north.

\section{Wandjina Spirits}

The onset of the summer rains triggers Aboriginal ceremonies across the tropics. Aboriginal people in the Kimberley region of northern Western Australia consider that wandjina spirits, which have a form both humanlike and cloudlike, are important for controlling the northern tropical "Wet Season" (Crawford 1968, McCarthy 1953, Mowaljarlai \& Malnic 1993). Aboriginal people sing to these spirits to keep them calm during the monsoon. In paintings, their figures may be represented in full, with arms or legs, or as just the head and halo, or reduced to the extreme as eyes peering through the halo. The Wandjina's headdress symbolizes clouds, while the strands of material coming from the hair can represent either feather decorations or lightning.

The Wandjina spirits are believed to reside in caves where their bodies are painted on the walls. Approaching the caves requires adherence to strict protocols, such as visitors identifying themselves and stating their reason for coming. Crawford warned that "Should the Wandjinas be offended, the Aborigines believe that they will take their revenge by calling up the lightning to strike the offender dead, or the rain to flood the land and drown the people, or the cyclone with its gales to devastate the country" (Crawford 1968).

\section{Lightning and Thunder Spirits}

The Gunwinggu people in central Arnhem Land believe that Lightning Man Namarragan produces lightning by smashing his edge-ground stone axe into trees (Isaacs 1980, Jones 1985a, Jones \& Meehan 1997). In Aboriginal paintings, Lightning Ancestors are often depicted with axes tied to their knees and elbows, and white 
waistbands representing lightning (Chaloupka 1993). In the Western Desert, Pintupi and Luritya people discerned two types of lightning, with the explanation that Lightning Men throw jagged bolts to hit trees, while Lightning Women make the sheet lightning that illuminates clouds (Hansen \& Hansen 1992).

Aboriginal people appealed to their Ancestors for control of lightning and thunder. Mathews claimed that in the Wollongong region of coastal New South Wales:

If very bad thunder and lightning occur during the night, the old men hold burning sticks in their hands and call out to Merribi, the thunder, to go away to another place which they named, and request him to take the lightning with him as a torch, to show him light to fish for bulundyulung, a small black fish. (Mathews 1904)

In the southern Eyre Peninsula district of South Australia, Aboriginal people believed that Ancestor Pulyallana caused thunder with his fits of rage and by storming about the clouds, while lightning was produced by him jerking open his legs (Schürmann 1879, Wilhelmi 1861). In the Lower Murray region of South Australia, thunder was regarded as the voice of male Supreme Ancestor Ngurunderi, while rainbows showed him urinating (Taplin 1879).

\title{
Constellations
}

Aboriginal people believed that the heavens formed a Skyworld, where the spirits of the deceased resided alongside the Ancestors (Clarke 2003, Johnson 1998). As a landscape, it was believed to contain animals, plants and water bodies. In western Victoria, MacPherson claimed the constellation:

\begin{abstract}
Berenice's Hair, which is in the meridian at midnight in the month of March, is a tree with three principal branches. Now, although a shower of rain has come, the dusty and gaping earth has soaked up every drop of water that has fallen upon it. A small cavity, however, formed at the junction of the three branches of a tree retains some of the precious fluid, and here a number of birds are represented as drinking, and the scene is transferred from the earth to the skies. (MacPherson 1881)
\end{abstract}

For Aboriginal hunter-gatherers, observations of star movements were important indicators of changing seasons. Palmer reported that Aboriginal people in northern Queensland "have learnt to associate the recurrence of these [astronomical] changes with the ripening of particular fruits, or the visitations of certain animals, on which their subsistence depends" (Palmer 1885).

In the tropics, the arrival of particular constellations in the night sky heralded the end of the monsoon. Haynes recorded that on Groote Eylandt:

The appearance in the evening sky towards the end of April of two stars (Upsilon and Lambda Scorpii) in the 'sting' of the constellation of Scorpio indicated that the wet season had ended and that the dry south-easterly wind marimariga would begin to blow. (Haynes 1992)

Haynes recorded that "When Arcturus could be seen in the eastern sky at sunrise, the Aborigines of Arnhem Land knew that it was time to harvest the spike-rush [Eleocharis dulcis] or rakia, a reed valuable for making fish traps and baskets for carrying food, and 
a local legend about Arcturus serves as a reminder of this" (Haynes 1992). In the Wide Bay district nears Cairns in northern Queensland, Aboriginal foragers knew by the position of the Orion constellation when the honeysuckle banksia (Banksia dentata) in the inland ranges had flowering cones ready for collecting nectar (Palmer 1885).

Across the arid zone, the Pleiades were widely associated with winter weather. For Western Desert people, the observation of the returned rising of the Kungkarangkara (Pleiades) constellation in the May dawn sky, after it had been invisible for some months below the horizon, signals the beginning of the season of nyinnga (njenga, literally 'ice'), a frosty period that runs until September (Clarke 2003, Haynes 1992, Rose 1997, Tindale 1959, 1972). At this time it is generally cold and dry, with occasional anticyclonic storms from the south. For Western Desert people, such as the Anangu Pitjantjatjara, the arrival of Kungkarangkara triggers the commencement of ceremonies associated with the increase of dingoes or wild dogs, as nyinnga is their birth season.

The Pleiades constellation was seen by many Australian Aboriginal groups as a number of women fleeing from men (Clarke 1997). These Ancestors were widely credited with making cold weather. Mathews recorded that in central New South Wales:

Among the Ngeumba [Ngiyambaa] blacks, in the cold weather of mid-winter, when the Pleiades rise about three or four o'clock in the morning, the old men take some glowing coals on bark shovels, and cast them towards this constellation as soon as it is visible. This is done to prevent the spirit-women, whom these stars represent, from making the morning too cold. The women in the camp are not permitted to look at all the Pleiades in winter nights, because such conduct would increase the severity of the frost. If a woman transgress this law, her eyes will become bleary, and she will suffer from uterine troubles. (Mathews 1904)

In the Mulligan River area of the border country between South Australia and Queensland, it was Aboriginal belief that the Pleiades women had the power to bring on the cold season, and then later cause the warm weather to return (Fraser 1901).

In temperate southeastern Australia, Mathews noted that Aboriginal people understood that "the stars which occupy the northern sky in the cold winter evenings travel on, and are succeeded by others in the following season; and that these are again displaced by different constellations during the warm evenings of summer" (Mathews 1904). In Tasmania, Robinson stated that "The natives showed me the three stars which they say is a sign the fine weather is coming and when those stars are verticle [sic.] the fine weather is come" (G. A. Robinson 30 June 1834 cited Plomley 1997). By Plomley's reckoning, the stars are probably the two Pointers and one of those in the Southern Cross. He calculated that the vertical alignment occurs on 1 December.

\section{People as Weather-Makers}

The variable Australian climate and uncertain weather patterns, leading to periods of drought and flood, from time to time create serious shortfalls in Aboriginal sources of food and water. McCarthy described "magic" for Australian hunter-gatherers as "a link 
with the unseen powers of Nature and a medium for gaining some measure of control over them" (McCarthy 1953). According to Rose, desert dwellers consider that "rain cannot occur unless the appropriate ceremonies are performed by them. So close is the self-world relationship that they consider the rain to be as dependent on them as they are on it" (Rose 1956).

Many Central Australian Aboriginal groups have totemic affiliations to rain. At Tennant Creek, the Warumungu people have Ngappa Wirnkarra or Rain Dreaming (Simpson 1997). There were also "Rain" people among the Wangkangurru at Parapara in the Simpson Desert, an Eastern Arrernte group at Aljoa on the Hale River; and a Southern Arrernte group at Iibora on the Lower Finke River (Strehlow 1970). Aboriginal rainmakers appealed to their Dreaming Ancestors when making rain. During severe droughts, Diyari rainmakers at Cooper Creek in northeast South Australia declared to their Ancestors that their countrymen were suffering because their land was dry and food scarce (McCarthy 1953). In the Kartwiakwatja rain country, east of Alice Springs, a local clan possessed rainmaking rituals they attributed to the Rain Ancestor Irtj-woanga (McCarthy 1953, Spencer \& Gillen 1899).

While particular individuals were regarded as powerful rainmakers, the rituals to create rain were not restricted to one class of person. Depending on the region, both men and women could be rainmakers, or at least involved in the ceremony (McCarthy 1953). There are many ways in which Aboriginal people obtain knowledge of how to change weather. In the case of formally initiated "medicine-men" who made rain, they believe that they have received their "magical powers" either from an Ancestor or from spirit beings like the Rainbow Serpent (Elkin 1977, McCarthy 1953). Some "powered men" received their knowledge of rain rituals, and often the "tools" too, during psychic travels to the Skyworld (Dawson 1881, Eyre 1845, Smith 1880, Teichelmann \& Schürmann 1840). It is Aboriginal belief that rainmakers actually visit the Skyworld to pull apart the clouds for the purpose of creating rain (McCarthy 1953).

Apart from learning rituals from established practitioners, weather-makers sometimes dream of new methods (McCarthy 1953). They may also observe certain incidents that appear to produce weather, and from its associated activities they develop rituals. In the Flinders and Saxby River region of the Gulf of Carpentaria, Palmer observed that for rainmaking:

\footnotetext{
The means adopted, by those who have this faculty, are as curious as various. Some of the Gulf tribes skin a native cat (Dasyurus), and hang it in a tree; or break up mussel shells, with the fish in them, and return the material to the water; others gather up dust, throw it into the air, and then blow upon it with their breath; whilst others, again, steep the entrails of opossums in water, accompanying the operation by the performance of certain ceremonies. (Palmer 1885)
}

Based upon empirical evidence, weather-makers would probably have on occasion modified or augmented their rituals. When local attempts to alter the weather had failed, prestigious individuals with widely acknowledged abilities in weather-changing would be invited into camp from surrounding areas. In Aboriginal belief, failure in ritual is best explained in terms of such causes as faulty procedure, a member of the group breaking a taboo, or interference via the sorcery of enemies. 
Control over weather was attractive to Aboriginal people for reasons beyond providing drinking water and temperature relief. To help with their stalking, hunters preferred to remain hidden from their game. From inland eastern New South Wales, Mathews recorded that:

Dhuran is the Wirraidyuri [Wiradjuri] name for what we call "wind-clouds." When such clouds are seen in the sky in the early morning, the men whistle for the purpose of causing the wind to arise and then start out into the bush. Kangaroos, emus and similar game generally keep their heads facing the wind, making it more easy for a hunter to approach them in the rear. Besides, the wind prevents them from hearing small noises, as the crackling of sticks under a man's feet, or catching the scent of hunters. (Mathews 1904)

McCarthy provided an example of how the ability to change weather was seen as an advantage for concealing tracks. He claimed that:

When a man has committed a crime and wishes to escape the resultant revenge of his victim's kin, or when he is eloping with a woman belonging to or intended for another man as his wife, he may perform a rite to create a local shower that will obliterate his tracks. In the same way, a hunter may desire rain to make tracks easy to follow and to tire a kangaroo in boggy ground. (McCarthy 1953)

Weather-making was also performed as a form of sorcery. In the Gulf of Carpentaria, Palmer noted that Aboriginal people "can, as they think, command the thunder and lightning, the wind and the storm, to aid the accomplishment of their evil purposes, but have also special methods" (Palmer 1885).

Aboriginal people often suspect their neighbours of preventing the change of season or for delivering bad weather. At Yarralin in the tropical Northern Territory, Aboriginal people blame their western neighbours for delaying the onset of the Wet Season, when it is late, stating that they "hold it back" (Rose 1997). Here, too much rain is another potential problem, with special songs and rituals used to convince the wind and the sun to halt the rain. In the Western Desert, Anangu Pitjantjatjara people blame sorcerers for creating the severe frosts that kill the mulga (Acacia aneura) scrub (Tindale 1972). Groups living in the Western District of Victoria feared their neighbours, the Buandik (Bungandaetch) people from Mount Gambier in the southeast of South Australia, for their supposed ability in sending them lightning and heavy rain to cause them injury (Dawson 1881). This perception would have in part been based upon the direction from where the anticyclonic weather originated. The motivation for sending storms to a neighbour's country may have been in order to prevent them hunting and fishing, or to conceal a party of warriors on a revenge expedition (McCarthy 1953).

Aboriginal hunter-gatherers required an ability to read subtle changes in the environment. Northern European settlers, arriving in Australia, were confused by the climate to the extent that they often consulted Aboriginal weather forecasters. According Robinson, the Tasmanians "had attained to such celebrity that my people, i.e. white men, would consult them on this subject [the weather], and always appeared satisfied at what the natives told them" (Robinson 1830 cited Plomley 1966). 


\section{Weather-making "Tools"}

The primary "tools" for altering weather were rituals, which sometimes included the use of physical objects and materials. Tasmanian Aboriginal people would thrust a burning stick into the air in the direction to which they wanted the wind to start blowing (Robinson 1830-31 cited Plomley 1966). Desert-dwellers living east of Lake Eyre in Central Australia used "the enchantment of the sun", which was a piece of earth from Ditji-mingka (literally "Sun-cave”), for making warmer weather (Hercus 1987). The desert is a bitterly cold place at certain times of the year. At Bentinck Island in the Gulf of Carpentaria in Queensland, Kayardilt people threw boomerang-shaped charms made from bark to induce a wind change. ${ }^{3}$ During the 1970 s, Wik people living on Cape York Peninsula in northern Queensland would try to repel approaching tropical thunderstorms by cutting them with a knife, or at least by making cutting movements in their direction holding a knife (Sutton pers. com.). The Wik had reason to fear them, as people were occasionally killed by lightning. It was Wik belief that light attracted lightning, so when storms loomed at night time all lights in their settlement were put out, and in spite of the stifling conditions, all doors and windows had to be closed.

For Aboriginal people, their perceived abilities to make rain relied upon the combined strength of their rituals and rainmaking gear. To bring rain, Aboriginal people in northwest Queensland imitated the calls and movements of frogs (Roth 1897). In the Western Desert and Central Australia, pearl shell ornaments traded inland from the Kimberley are used in rainmaking rituals (Akerman 1994, McCarthy 1953). For these objects, the symbolic link to rain may come from the property of refracting light into "rainbows" (Sutton \& Snow in press). Kimber remarked upon desert rainmaking practices of Aboriginal men at "rain centres" on the edge of the Simpson Desert, such as at Charlotte Waters and Aruabara:

Over several years I have noted that they observed the water-absorber mineral gypsum, and, on perceiving moisture-induced changes or deliberately moistening the gypsum to promote such changes, crushed the mineral to free the water spirit. At other places they crushed the white shells of desert-dwelling snails so that they glistened like hail. (Kimber 1997)

Here, the crushed snail shells were thrown into the air to fall like real hailstones, a "rain making" practice similar to that which Anmatyerr men of northern Central Australia described for me during fieldwork in 2008.

Anangu Pitjantjatjara people of the Western Desert possess rainmaking practices associated with "rain-sticks" (Tindale 1972). To fetch the southerly rain-bearing clouds they also wave in the air branches of the red mallee (Eucalyptus oleosa), the roots of which contain drinking water. Across Australia, there would have been many rainmaking rituals, some peculiar to individual rainmakers. A Wiradjuri rainmaking ritual from inland eastern New South Wales was described as follows by Mathews:

An old man took the rump of an emu, the bone of a kangaroo's leg and a white stone, all tied together. He then dived into a hole of water, carrying the parcel with him to the bottom, for the purpose of saturating it with water. On coming to the surface again, he swayed it backward and forward toward the west, muttering incantations all the time. If 
he happened to see a fragment of cloud coming up, he put the apparatus into the waterhole near the bank, and waited for the rain. (Mathews 1904)

Mathews recorded an account from the Wollongong region of coastal New South Wales for bringing down showers:

A muyulu or doctor got a piece of kurrajong [Brachychiton populneus] bark, which he laid on a $\log$ and beat with a stick till it became soft and flexible. Then he took some stringybark [Eucalyptus obliqua] and pounded it in the same way and wrapped it around the kurrajong bark, and bound the whole with string. This parcel was placed in a water hole, and was believed to have the power of causing rain. (Mathews 1904)

McCarthy (1953) outlined similar rituals in Arnhem Land, involving the use of fishpoisons prepared from the bark of various tree species. This material was pounded, and then made into a bundle for dropping into the lagoon, accompanied by a song about falling rain, followed by water splashing. Rain clouds were expected to form after three days, and the rain to fall after four.

In the mallee area of western Victoria, rainmakers manufactured a ball from their own hair, and then soaked it in water (Dawson 1881, Massola 1966). While chanting, the rainmaker sucked water from the ball and then squirted the liquid from the mouth towards the west, from where the wet winter weather chiefly comes. In eastern Victoria, Kurnai people ritually created rain by squirting water in the direction from which showers generally arrived, and both men and women sang rain chants (Howitt 1904, McCarthy 1953). During the 1980s in the Lower Murray region of South Australia, Ngarrindjeri man Henry Rankine demonstrated this ritual for me, threatening to use it to sabotage the holding of an outdoor event of which he did not approve. Along the east coast of Australia, the burning of human hair was the basis of other rainmaking rites (McCarthy 1953).

Objects known as "rain stones" were widely used. In western Arnhem Land, stones representing Rainbow Serpent eggs were painted with designs associated with rain to bring on the Wet Season (McCarthy 1953). A type from central northern Victoria was a smooth white round stone, which was placed in water when rain was wanted, and taken out and carefully dried and placed in a rainmaker's bag when it was no longer required (Stone 1911). Similarly, in the Darling River district of western New South Wales, an object made from crushed gypsum, human blood and hair was attached to a stake in the river, with the rain said to arrive when the paste had dissolved away (McCarthy 1953). At Georgina River in western Queensland, quartz crystals were thrown, representing rain, over women who caught them in wooden containers (McCarthy 1953). Crystals of quartz, calcite and gypsum were widely used to make rain (McCarthy 1953, Palmer 1885, Rose 1997, Roth 1897). They were often associated with Rainbow Serpents, possibly because of their refractive light properties that simulated rainbows, which were seen as power sources for rain production (Brown 1930).

Ceremonies involving ochre were performed in order to maintain water levels for the sake of fish supplies. Howitt related that:

There is a spot at Lake Victoria [Lake Alexandrina], in the Narrinyeri [Ngarrindjeri] country, where when the water is, at long intervals, exceptionally low, it causes a tree-stump to 
become visible. This is in charge of a family, and it is the duty of one of the men to anoint it with grease and red ochre. The reason for this is that they believe that if it is not done the lake would dry up and the supply of fish be lessened. This duty is hereditary from father to son. (Howitt 1904)

Aboriginal people considered themselves as having a role in the maintenance of environmental resources. Such responsibilities were held by clans on the basis of their affiliations with specific Ancestors.

In 1984, an Adnyamathanha man from the northern Flinders Ranges provided me with an account of his "grandfather" using a "drought stick" in the late nineteenth century to punish a pastoralist who had killed his dogs (see also Isaacs 1980). It was driven into the ground to cause a drought, and when not in use was kept hidden in a cave. Aboriginal people used smoke as a tool to stop rain. In Central Australia, desert dwellers believe that they can drive away clouds causing too much rain by burning kerosene-bush (Eremophila sturtii) to create smoke (Latz 1995). In 1986, while I was on a fieldtrip to the Sturt Stony Desert, west of Innamincka in northeast South Australia, Wangkangurru man Jimmy Harris performed for me a similar ritual, when he lit up a pile of dry branches leaning against a coolibah (Eucalyptus microtheca) tree that made smoke intended to stop a downpour of rain.

\section{Weather-making Places}

The perceived success of rituals was dependant upon the power of the location where they were performed, or from where the materials used were originally obtained (Mathews 1904). East of Lake Eyre in Central Australia, Aboriginal people believed that hot weather could be generated at Ditji-mingka, where the Sun first rose from the ground (Hercus 1987). Kimber remarked that "rain centres", like the great "Rain Dreaming centre" at Dalhousie Springs, were generally places of hilly terrain, which received their power to create rain and hail through the Ancestors (Kimber 1997). A ritual performed at Dalhousie Springs involved imitating the cry of the plover, a wetlands bird species (Kimber 1997).

The Adnyamathanha people of the northern Flinders Ranges believe that two gumtrees growing at Milyaru Wayakanha Awi Urtu waterhole have power over the weather. Tunbridge recorded that "In very hot weather, people would go to these trees and hit them with a stone or a stick or some such thing, in order to bring about a change in the weather. The trunks appear to bear the record of many years of having been hit" (Tunbridge 1988). Striking the trees was thought to bring on a cool change, which was then usually followed by a dust storm. Such trees are seen as harbouring powerful forces, derived from the Dreaming itself.

\section{Indigenous Time}

Prior to European settlement in Australia, Aboriginal people did not precisely measure space and time. Most Aboriginal languages did not have a numbering system with terms beyond five, although if Aboriginal people needed to they could count higher in 
multiples of five (Harris 1987, Tindale 1978). Daytime was marked by the position of the sun, while the number of days and moons accounted for longer periods. Roth claimed that "Beyond a few months' duration, Time-when cannot be accurately expressed: reference is made to some event of more than passing importance-such as a big flood, or drought, or some special initiation ceremony, or a tribal fight, perhaps" (Roth 1897).

Rather than focusing upon the measurement of time, Aboriginal hunter-gatherers watched for changes in the environment which heralded the onset of each season in their calendar (Clarke 2003, Davis 1989, 1997, Reid 1995). Rose gave an example from Yarralin in the Northern Territory of the Aboriginal observation of "messages":

Crocodiles vary their behaviour from year to year; using the western calendar it is only predictable that they will usually start to lay eggs between late August and late September. But for Yarralin people the event is completely predictable: the marchflies tell them. (Rose 1997)

In a variable climate, relying upon environmental cues to indicate the change of season, rather than the counting of a fixed numbers of days as with modern European calendars, has its advantages.

For Aboriginal foragers, the resources embedded in the land were available according to the seasons, a major factor in driving Aboriginal movement patterns. Bates stated that:

These seasons appear to be periods when certain roots and other foods are ripe. In his own district a native knows exactly the localities where certain roots and other vegetable foods grow, the proper time of ripening and the readiest means of obtaining them. His camp is continually shifted to that portion of his territory which contains the greatest abundance of certain root and other foods, and remains in the vicinity until the supply of such food is exhausted. (Bates 1901-14 [1985])

For hunter-gatherers, particular plant species were like a "bush calendar", being crucial for keeping track of where they were in the seasonal cycle (Clarke 2007). Robinson stated that "The natives calculate the times of the seasons by various methods. Hence I enquired of the TYREELLORE woman when the time was for the mutton birds to come in and they shewed me the lightwood tree [Acacia melanoxylon] that was near them and said that when that tree was in blossom the mutton birds would be in" (Robinson 1832 cited Plomley 1966). The Kuku Yalanji people of Mossman Gorge in northern Queensland know that when the black bean (Castanospermum australe) is ready for foraging, it is time to catch jungle fowls (Roberts et al. 1995).

Aboriginal people used their knowledge of the seasonal availability of resources to maintain what Stevenson (1985) referred to as a high production/labour input ratio. This characteristic of hunter-gatherer lifestyles was a major factor behind Aboriginal fire management practices and in driving Aboriginal movement patterns. The hierarchy of Aboriginal food preferences places higher value on foods which are either considered tasty or, due to their bulk, are easily procured, while there is less value for highly fibrous sources or those which are more labour-intensive to gather and prepare (Clarke 2003, 2007). If the season is severe, Aboriginal foragers consumed "hard time" 
foods not normally utilized. When the high productivity of the season allowed, certain areas were able to support short term increases in the Aboriginal population for the purposes of holding religious ceremonies, trading, dispute resolution and organizing marriages (Clarke 2003, 2007).

European settlers and their descendants have continued to interpret the Australian climate according to a cold temperate Northern Hemisphere model of four seasons, even when there is a poor fit. Elkin commented upon this resistance of European Australians to adopt specific indigenous calendars, "But each [indigenous] calendar is a local one. We stick to our four seasons wherever we are, like plum-pudding for Christmas on the equator or in the Antarctic, although we know that in some regions this is often an unreal division of the year" (Elkin 1964). During recent years, in limited ways there has been a growing awareness that Aboriginal seasonal "calendars" are more relevant and reflect to a greater extent the nature of the Australian environment (Jones et al. 1997, Reid 1995).

The term "calendar" is used to describe the temporal division of a year, although Aboriginal perceptions of seasons often span greater periods, particularly in arid regions with irregular rainfall. Apart from those of the desert, most seasonal calendars in Aboriginal Australia have more than four divisions. The timing and length of the season varies from year to year. This creates problems when teaching Aboriginal calendars in schools by artificially linking indigenous seasons to fixed periods on the European calendar (Hoogenraad \& Robertson 1997, Simpson 1997). The recognition and adoption by European Australians of indigenous models of seasonal change is beginning to occur in monsoonal Australia, where a number of detailed studies of Aboriginal seasonality have been produced (Breeden \& Wright 1991, Rose 1996). Here, national park authorities increasingly use this knowledge to help manage the environment by controlling the fire regime.

Indigenous calendars provide a better seasonal fit in most parts of Australia, because they are based upon cues and cycles within each environment. Different seasons are identified or signalled by distinct animal, vegetation, mythic and totemic associations, climatic events and patterns, and varied by intermittent landscape firings and floods. The movement of celestial bodies in the Skyworld are important too. In hunting and gathering times, local calendars were shared by many, although with no single correct seasonal model of living being possessed by all. Men and women, each with specific strategies for obtaining food, would have had different activities tied to seasonal changes (Berndt 1981, Clarke 2003, Kaberry 1939).

\section{Tropics}

Europeans living in tropical northern Australia have typically recognized just two main seasons: the "Wet", when most yearly rainfall occurs, which commences with monsoonal rains in late December; and the "Dry" starting around May. Increasingly, European Australians are also recognising a third season, the "Build-up" leading into the "Wet". During the height of the Dry Season, much of northern Australia is shrouded in smoke from countless fires. 
The detailed study of Aboriginal calendars begins with Thomson in the tropical north. Concerning the Wik people of Cape York Peninsula, he described five seasons, "each with its distinctive and characteristic climatic and other conditions, and each related to a food supply, and hence to a definite kind of occupation" (Thompson 1939). He later noted that Aboriginal people in Arnhem Land divide the year into six or more seasons and:

state without hesitation the appropriate occupational sites at each of them, and their activities and food supplies which depend upon the seasonal conditions, with an insight and a precision that no white man who is not a trained ecologist and well versed in botany and zoology, could approach. (Thomson 1949)

Aboriginal hunter-gatherers utilized their models of the seasons to strategically place themselves in the landscape (Sutton in press).

Research into Aboriginal relationships to the environment has revealed that in the northern Kimberley region of Western Australia, the Aboriginal inhabitants have calendars with between five and nine seasons (Crawford 1982, Kaberry 1939, Reid 1995, Smith \& Kalotas 1985). There are six seasons recognized by groups living in the Top End of the Northern Territory (Breeden \& Wright 1991, Davis 1989, Hiatt \& Jones 1988, Jones 1985b). The Yanyuwa people living in the McArthur River region in the southern Gulf of Carpentaria, Northern Territory, possess five seasons in their calendar (Baker 1999). At Aurukun in western Cape York, Queensland, the Wik people have seven seasons (Aurukun School \& Community Calendar 1985, McConnel 1930, Reid 1995). The Alngith people at Weipa the tip of western Cape York count five (Reid 1995), as do the speakers of Wik-Ngathan living at Cape Keerweer (Chase \& Sutton 1981, 1987, Sutton in press). On the eastern side of Cape York, the Umpila-speaking people between Princess Charlotte Bay and Lockhart River structure their calendar with six seasons (Chase \& Sutton 1981).

In many Aboriginal languages, the references to the seasons are descriptive. The Bardi people in the western Kimberley list six seasons in their calendar (Smith \& Kalotas 1985). The period called ngalandany commences after the monsoonal rains towards the end of January, and its name literally means "no fruit". This is seen as a "rubbish time", with high temperature and much humidity, with little or no wind. In Arnhem Land, the Gidjingali people refer to barparanga, or the late Dry Season, as "hot sand time" in English (Jones \& Meehan 1997). At this time of the year, from the beginning of August to the end of November, the sands of the coastal dunes are too hot to walk on with bare feet, without bindings of paperbark, or more recently rubber thongs. In my experience, the varieties of Aboriginal English and Kriol spoken across Australia, the rainy seasons are often described as "green time" or "rain time". In some Cape York Peninsula languages, the term for the Wet Season is also extended to mean "year", with a "bad year" referring to larger than normal Wet Season rains (Alpher 1991, Kilham et al. 1986, Sutton pers. com.).

In tropical coastal regions, Aboriginal people generally moved between camps at distinct "Dry Season" and "Wet Season" locations, with different modes of living at each place (Sutton in press). In the north, Thomson remarked: 
Within the bounds even of a single clan territory a people may spend several months of the year as nomadic hunters, in pursuit of bush game, wild honey and small mammals, and exploiting the resources of vegetable foods of which a great number are known. A few months later the same people may be found established on the sea coast in camps that have all the appearance of permanence or at least semi-permanence, having apparently abandoned their nomadic habits. (Thomson 1939)

The architectural style of camp shelters changed dramatically through the course of the year (Memmott 2007, Thomson 1939). By constantly moving according to their reading of seasonal indicators, Aboriginal foragers in the tropics maximized the availability of their resources while minimizing the labour required for making a living. As with other climate zones, the environment around favoured camping sites was able to regenerate between periods of occupation.

In addition to hunting and gathering activities, Aboriginal calendars structured ceremonial life. For the Yanyuwa people of the MacArthur River area in the southern Gulf of Carpentaria, their main Wet Season, lhabayi, generally runs from early January to mid March (Baker 1999). The last few weeks of the season is noted for its cyclonic winds and forceful "knock-him-down" rains, which flatten the grass. Rra-mardu, with its southerly winds, is the cool season which usually starts in early April and goes through to the end of July. There is little rain, but lots of dew and coastal fog. Major Aboriginal cult ceremonies are organized for this season. By August to early October it starts becoming warm, with this period known as ngardara. The winds shift around to come in from the north across the sea. The season of na-yinarramba is the build up before the Wet Season proper, with winds becoming more westerly. The commencement of wunthurru in early December is marked by the first Wet Season storm, followed by heavy showers. The male initiation ceremonies are held at this time, and usually stretching into the thabayi season.

Tropical calendars in the coastal north of Australia were influenced by the former annual arrival of Asian seafarers. From the seventeenth century, these visitors, who came mainly from southern Sulawesi, arrived with the northwest monsoon and returned with the trade winds (Berndt \& Berndt 1954, Campbell 2002, Clarke 2003, Thomson 1949, Warner 1937 [1964]). In many Aboriginal languages of coastal Arnhem Land, the names of three of the main winds were derived from MacassanMalay words for compass points: barra (northwest monsoon) comes from barat (west), djimarru (southeast trade wind) from timur (east) and djalata (south wind) from selan$\tan$ (south) (Jones 1985b, Jones \& Meehan 1997). ${ }^{4}$ At Yirrkala in northeastern Arnhem Land, the appearance of Scorpio in the morning sky in early December forecast the arrival of Asian fishermen in their prahus to collect trepang or sea slug (Mountford 1956).

\section{Arid Zone}

Australian deserts have seasons that are not truly cyclical, although they do recur within patterns, albeit at irregular intervals influenced by the El Niño-Southern Oscillation (Clarke 2003). Europeans have generally not recognized that deserts have any 
discernable seasons (Bindon \& Gough 1993). In areas, such as Central Australia, this variability makes the translation of indigenous terms for calendar periods into specific months particularly difficult. Desert calendars indicating fixed periods are less reliable than those for the tropics. In Central Australian languages, such as Warlpiri, linguist Robert Hoogenraad and Aboriginal man George Jampijinpa Robertson claimed "A feature of the terminologies is that there tend to be several synonyms, and that there appear to be no primary terms for seasons: they are either extended usages, or compounds built on other terms" (Hoogenraad \& Robertson 1997). The examples they give include the hot season wantangka, based on the words wanta, for "sun", and ngka, as a locative ending (that is, "at", "in" etc.).

The monsoonal rains blowing in from the northwest begin to influence Central Australia from December, there being a several week lag from the northern coastal seasons as the winds change to the south (Kalma \& McAlpine 1983). The clouds are largely emptied of water by the time they reach this far inland, producing irregular and scattered rainfall. This is reflected in how Aboriginal people classify clouds according to their rain-bearing properties. In the Western Desert, Pintupi and Luritya people distinguish between two types of clouds: ngangkali is a rain cloud, while yaarrka is misty and rainless cloud (Hansen \& Hansen 1992). In northern Central Australia, some of matrilineal totems are subdivisions of cloud types (Sutton pers. com.). Across Australia, the impact of the monsoon declines from north to south, as the influence of anticyclonic weather increases.

In the desert, the combination of warm weather and rain stimulates the production of plant foods. For the Arrernte people of the MacDonnell Ranges in Central Australia, this occurs in the hot and rain season of uterne which runs from December to March (Henderson \& Dobson 1994). When the sun is out, the ground becomes too hot to walk on. This is the time of the year to collect fruit such as wild oranges (Capparis mitchellii), desert bananas (Marsdenia australis) and wild tomatoes (Solanum chippendalei). In Arrernte perception, the sun "cooks them ripe". It is also a good time to dry chewing tobacco (Nicotiana species). Starting in April, the season of alhwerrpe makes the desert colder and drier, being equivalent to the southern temperate winter. The season of ulpmulpme, from October to November, is windy and brings some rain, although less than with uterne. It is a period when the land starts to become green through growth in leaves, flowers and seeds.

Western Desert people recognize from three to five main seasons of the year. Here, there have been specific studies of the Aboriginal seasonal calendars related to the country around Uluru (Ayers Rock), Kata Tjuta (the Olgas) and the mountains in the North West of South Australia (Goddard 1992, Mutitjulu Community \& Baker 1996, Tindale 1933, 1957, 1972, 1978, 1981). For the Walmadjeri people living in the Sandy Desert of Western Australia, there has been a detailed study of the calendar, which is divided into four main seasons (Tindale 1974).

Desert dwellers were forced by drought to travel far to find food and water, and there was a constant concern about how the severity of the season affected their neighbours. Tindale claimed that "In the Western Desert a widespread term for strangers is ngatari, a word linked with the season of whirlwinds in hotter and drier months of the year, 
when drought could, in bad years, make forced evacuations necessary by desperately water short 'foreigners', potential menaces to those more securely based" (Tindale 1981). Aboriginal groups who primarily relied on the small rock holes for their water were the most likely people forced to raid the lands of their better-watered neighbours in drought times.

\section{Temperate South}

The seasonal calendars for much of temperate Australia are either imperfectly known or not recorded at all, due to the early cessation of hunter-gatherer life styles in the face of intense European colonization in this zone. In spite of this, enough early foraging strategies are mentioned in the historical records to show a behavioural pattern, even when the indigenous terminology for seasons is unknown. Calendars in temperate Australia appear to have contained at least the same number of seasons as the Northern Hemisphere temperate region, and often more. For example, in the Swan district of southwest Western Australia, Aboriginal people recognized six seasons: mokurwinter, about June and July; jilba—spring, August and September; kambarong-late spring, October and November; beeruk-summer, December and January; boornorearly autumn, about February and March; and winyarung — mid to late autumn, April and May (Bates 1901-14 [1985], Bindon \& Whalley 1992). As with the tropics and desert regions, each season would have had a distinct combination of wind direction, rainfall, temperature and environmental resources.

In the Murrumbidgee to Lower Darling region of inland New South Wales, four seasons were recorded for the Aboriginal calendar. These are kurtie-summer, distinguished by flowers and fruit; weat - autumn, known for the gossamer threads in the air and as the season that reptiles become inactive; miangie-winter, a hard time for Aboriginal people beginning with frosts; and bakroothakootoo-spring, a time of succulent herbs and the breeding of birds and kangaroos (Beveridge 1884). There is also a partial account of the seasonal calendar for the Bigambul people in the Riverine district, on the eastern side of the border between Queensland and New South Wales. Howitt claimed:

\footnotetext{
The seasons are reckoned by the Bigambul according to the time of the year in which the trees blossom. For instance, Yerra is the name of a tree which blossoms in September, hence that time is called Yerrabinda. The Apple-tree [Angophora species] flowers about Christmas-time, which is Nigabinda. The Ironbark [Eucalyptus species] tree flowers about the end of January, which they call Wo-binda. They also call this time, which is in the height of summer, Tinna-koge-alba, that is to say, the time when the ground burns the feet. (J. Lalor cited Howitt 1904)
}

Here, presumably there were other seasons to cover the temperate autumn and winter months. The ebb and flow of floods may have been seasonal markers in some riverine districts.

In southwest Victoria, Dawson recorded a number of indigenous terms for weather, with storms classified according to the environmental damage they caused. In the Kuurn Kopan Noot dialect a storm "which destroys blossoms" was known as borran 
borran kula muutang, a storm "which blows young magpies out of their nests" was towitt towaek keerae, while a "hurricane" was puundeen knuurnduka (Dawson 1881). In the same dialect, Dawson listed summer as peep kaluun ("father of heat"), winter was gnuurnduuk ("cold") and spring as bukkar ya eeawan ("summer coming") (Dawson 1881). He claimed that there was not a term for autumn, although this may be a product of the poor fit between European and local indigenous calendars.

Most early authors working within temperate Australia appear to have collected terms that could be used in translations to approximate the four seasons of northern Europe, albeit six months out of phase. According to Stanbridge, in western Victoria the first season of the year was weeit (autumn), followed by myer (winter), gnallew (spring) and cotchi (summer) (Stanbridge 1857). This may well be an incomplete rendition of an indigenous calendar which has more seasons. In southwest Victoria, Aboriginal languages are rich with different terms for clouds and winds (Dawson 1881, Stone 1911). Here, in at least one language, there were different terms for the lunar phases (Blake 2003).

\section{Discussion}

Aboriginal understandings of the processes that produce the weather and the climate are heavily steeped in their mythological traditions. The cyclic pattern of seasonal changes was seen in the context of the Dreaming charter, while major disruptions, such as droughts and floods, were interpreted in terms of the actions of sorcerers and the non-compliance of religious protocols. Aboriginal belief in their Ancestors being the force behind the weather demonstrates how the Dreaming tradition is both of the past and the present. Aboriginal people observed environmental events as cues for specific activities, such as those concerned with hunter-gatherer strategies and ceremonial life.

In terms of research, scholars have varying interests in ethnometeorology. While linguists gain insights into the field by investigating atmospheric terminology, cultural anthropologists focus upon weather in their academic concern for how cultures formulate concepts about the natural world and the manner in which these are used as organizing principles in cultural and social life. Ethnometeorology presents opportunities for ecologists in developing a broader understanding of the relationships between climate and the landscape.

Research into the land-based knowledge possessed by hunter-gatherers is capable of providing scholars with a greater insight into the Australian environment. In remote regions, where the contemporary indigenous community is managing land, there is value in assisting Aboriginal people to retain elements of their former hunter-gatherer traditions that are threatened by modern sedentary lifestyles. This could be supported by increasing the role of local knowledge in ecological land management processes and through the education of indigenous children (Gambold 2002). For ecological knowledge to ultimately survive in any cultural environment, it must be proven to be useful in a range of contexts. One way of achieving this is through the documenting of seasonal calendars in educational institutions as a means for providing an appreciation of the breadth of relationships that indigenous people have with their country. 
In Australia, the study of indigenous seasonal calendars is a useful tool for the public to explore hunter-gatherer lifestyles as they were before British settlement. Indigenous calendars are used in museum exhibitions and national park interpretation centres as graphics for demonstrating how Aboriginal people interacted seasonally with the environment. ${ }^{5}$ While increasing globalization prevents European Australians from rejecting the European-derived calendar in favour of a plethora of regional calendars, the future investigation of indigenous seasonal knowledge and behaviour offers to help develop more relevant approaches to landscape management.

\section{Acknowledgments}

Peter Sutton provided very useful comments upon a draft of this paper.

\section{Notes}

[1] Wawalag is also spelt as Wauwalak and Wagilak.

[2] In recent times, Anangu Pitjantjatjara tour guides draw upon the Wanambi mythology during their ecotourism expeditions in Central Australia (see http://www.deserttracks.com.au/ experience.html).

[3] Artefact documentation for A52250. Collected by N.B. Tindale and P. Aitken at Wartad on Bentinck Island, Gulf of Carpentaria, Queensland, 1963. South Australian Museum Aboriginal ethnographic collection.

[4] See entries in Urry \& Walsh (1981) for ba: ra, dimuru, jalatang. Yolngu people in northeastern Arnhem Land also used the term, barra (Davis, 1997).

[5] Examples of indigenous calendars in displays are the Australian Aboriginal Cultures Gallery in the South Australian Museum, Adelaide and the Marrawuddi Gallery at the Bowali Visitor Centre in the Kakadu National Park, Northern Territory.

\section{References}

Akerman, K. (1994), Riji and Jakoli: Kimberley Pearlshell in Aboriginal Australia, Monograph Series 4, Northern Territory Museum of Arts \& Sciences, Darwin.

Allen, H. (1997), "Conceptions of Time in the Interpretation of the Kakadu Landscape", in Tracing Knowledge in North Australian Landscape, Studies in Indigenous and Settler Ecological Knowledge Systems, D. B. Rose \& A. Clarke (eds), North Australia Research Unit, Australian National University, Casuarina, Northern Territory, pp. 141-154.

Alpher, B. (1991), Yir-Yoront Lexicon: Sketch and Dictionary of an Australian Language, Mouton de Gruyter, Berlin.

Arthur, J. M. (1996), Aboriginal English. A Cultural Study, Oxford University Press, Melbourne.

Aurukun School \& Community Calendar. (1985), Seasons and Event Calendar, Aurukun Community, Northern Queensland.

Baker, R. M. (1999), Land is Life. From Bush to Town. The Story of the Yanyuwa People, Allen \& Unwin, Sydney.

Bates, D.M. (1901-14), The Native Tribes of Western Australia, I. White (ed.), (1985), National Library of Australia, Canberra.

Bates, D. M. (1925), "Serpent Cult of Aborigines", in Aboriginal Perth. Bibbulmun Biographies and Legends, P. J. Bridge (ed.), Hesperian Press, Perth, pp. 38-41.

Berndt, C. H. (1981), "Interpretations and 'Facts' in Aboriginal Australia”, in Woman the Gatherer, F. Dahlberg (ed.), Yale University Press, New Haven, pp. 153-203. 
Berndt, R. M. \& Berndt, C. H. (1942), "A preliminary report of field work in the Ooldea region, western South Australia”, Oceania, vol. 12, no. 4, pp. 305-330; vol. 13, no. 1, pp. 51-70; vol. 13, no. 2, pp. 143-169.

Berndt, R. M. \& Berndt, C. H. (1954), Arnhem Land. Its History and its People, F. W. Cheshire, Melbourne.

Berndt, R. M. \& Berndt, C. H. (1989), The Speaking Land. Myth and Story in Aboriginal Australia, Penguin, Melbourne.

Berndt, R. M. \& Vogelsang, T. (1941), "Comparative vocabularies of the Ngadjuri and Dieri tribes, South Australia", Transactions of the Royal Society of South Australia, vol. 65, no. 1, pp. 3-10.

Beveridge, P. (1884), "A few notes on the dialects, habits, customs and mythology of the Lower Murray Aborigines", Journal and Proceedings of the Royal Society of New South Wales, vol. 17, pp. 19-74.

Bindon, P. \& Gough, D. (1993), “Digging sticks and desert dwellers”, Landscope, Spring, pp. 11-16.

Bindon, P. \& Whalley, T. (1992), "Hunters and gatherers", Landscope, Spring, pp. 28-35.

Blainey, G. (1976), Triumph of the Nomads. A History of Ancient Australia, Sun Books, Melbourne.

Blake, B. J. (2003), The Warrnambool Language: a Consolidated Account of the Aboriginal Language of the Warrnambool area of the Western District of Victoria Based on Nineteenth-century Sources, Pacific Linguistics, Australian National University, Canberra.

Bradley, J. J. (1995), "Fire: Emotion and Politics. A Yanyuwa Case Study", in Country in Flames. Proceedings of the 1994 Symposium on Biodiversity and Fire in North Australia, D. B. Rose (ed.), Biodiversity Unit, Department of the Environment, Sport \& Territories and the North Australia Research Unit, Canberra \& Darwin, [Online] Available at: http://environment.gov.au/ biodiversity/publications/series/paper3/fire6.html

Breeden, S. \& Wright, B. (1991), Kakadu: Looking after Country - the Gagudju Way, Simon Schuster, Sydney.

Brown, A.R. (1930), "The Rainbow-serpent myth in south-east Australia", Oceania, vol. 1, no. 3, pp. 342-347.

Buchler, I. R. \& Maddock, K. (eds) (1978), The Rainbow Serpent. A Chromatic Piece, Mouton Publishers, The Hague.

Campbell, J. (2002), Invisible Invaders: Smallpox and Other Diseases in Aboriginal Australia, 1780-1880, Melbourne University Press, Melbourne.

Chaloupka, G. (1993), Journey in Time. The World's Longest Continuing Art Tradition. The 50,000year Story of the Australian Aboriginal Rock Art of Arnhem Land, Reed, Sydney.

Chase, A. \& Sutton, P. (1981), "Hunter-gatherers in a Rich Environment: Aboriginal Coastal Exploitation in Cape York Peninsula", in Ecological Biogeography of Australia, A. Keast (ed.), Junk, The Hague, pp. 1819-1852.

Chase, A. \& Sutton, P. (1987), “Australian Aborigines in a Rich Environment”, in Traditional Aboriginal Society. A Reader, W. H. Edwards (ed.), Macmillan, Melbourne, pp. 68-95.

Churches, S. (1992), "Aboriginal Heritage in the Wild West: Robert Bropho and the Swan Brewery Site", Aboriginal Law Bulletin, vol. 2, no. 56, pp. 9-13.

Clarke, P. A. (1997), "The Aboriginal cosmic landscape of southern South Australia", Records of the South Australian Museum, vol. 29, no. 2, pp. 125-145.

Clarke, P. A. (2003), Where the Ancestors Walked. Australia as an Aboriginal Landscape, Allen \& Unwin, Sydney.

Clarke, P. A. (2007), Aboriginal People and Their Plants, Rosenberg Publishing, Dural Delivery Centre, New South Wales.

Crawford, I. M. (1968), The Art of the Wandjina: Aboriginal Cave Painting in Kimberley, Western Australia, Oxford University Press, Melbourne.

Crawford, I. M. (1982), Traditional Aboriginal Plant Resources in the Kalumburu Area: Aspects in Ethno-economics, Records of the Western Australian Museum Supplement No. 15, Western Australian Museum, Perth. 
Davis, S. (1989), Man of All Seasons. An Aboriginal Perspective of the Natural Environment, Angus \& Robertson, Sydney.

Davis, S. (1997), "Documenting an Aboriginal Seasonal Calendar", in Windows on Meteorology. Australian Perspective, E. K. Webb (ed.), CSIRO Publishing, Melbourne, pp. 29-33.

Dawson, J. (1881), Australian Aborigines, Robertson, Melbourne.

Elkin, A. P. (1964), The Australian Aborigines. How to Understand Them, 4th edn, Angus \& Robertson, Sydney.

Elkin, A. P. (1977), Aboriginal Men of High Degree, 2nd edn, University of Queensland Press, St Lucia, Queensland.

Eyre, E. J. (1845), Journals of Expeditions of Discovery, 2 vols, Boone, London.

Fraser, A. (1901), "Hot and cold weather, and who caused it", Science of Man, vol. 4, no. 2, pp. 29.

Frazer, J. G. (1911), The Golden Bough. A Study in Magic and Religion. Part 1. The Magic Art and the Evolution of Kings, 2 vols, 3rd edn, Macmillan, London.

Gambold, N. (2002), "The Role of Traditional Ecological Knowledge and Skills in 'Modern' Aboriginal Land Management and Education”, in Planning for Country, F. Walsh \& P. Mitchell (eds), Jukurrpa Books, Alice Springs, pp. 142-147.

Gell, A. (1992), The Anthropology of Time: Cultural Constructions of Temporal Maps and Images, Berg, Oxford.

Goddard, C. (1992), Pitjantjatjara/Yankunytjatjara to English Dictionary, 2nd edn, Institute of Aboriginal Development, Alice Springs.

Gould, R. A. (1969), Yiwara: Foragers of the Australian Desert, Collins, London.

Hansen, K. C. \& Hansen, L. E. (1992), Pintupi/Luritja Dictionary, 3rd edn, Institute of Aboriginal Development, Alice Springs.

Harris, J. (1987), "Australian Aboriginal and Islander mathematics", Australian Aboriginal Studies, vol. 2, pp. 29-37.

Haynes, R. D. (1992), “Aboriginal astronomy”, Australian Journal of Astronomy, vol. 4, no. 3, pp. 127-140.

Henderson, J. \& Dobson, V. (1994), Eastern and Central Arrernte to English Dictionary, Arandic Languages Dictionaries Program, Language Centre, Institute for Aboriginal Development, Alice Springs.

Hercus, L. A. (1987), "Looking for Ditji-mingka", Records of the South Australian Museum, vol. 21, no. 2, pp. 149-156.

Hiatt, L. R. \& Jones, R. (1988), "Aboriginal Conceptions of the Workings of Nature", in Australian Science in the Making, R. W. Howe (ed.), Cambridge University Press, Melbourne, pp. 1-22.

Hoogenraad, R. \& Robertson, G. Jampijinpa (1997), "Seasonal Calendars from Central Australia", in Windows on Meteorology. Australian Perspective, E. K. Webb (ed.), CSIRO Publishing, Melbourne, pp. 34-41.

Howitt, A. W. (1904), Native Tribes of South-east Australia, Macmillan, London.

Isaacs, C. (1992) "The great rainbow serpent Dreaming track: part of one of the great religious belief systems of the world", Historic Environment, vol. 9, pp. 51-52.

Isaacs, J. (1980), Australian Dreaming: 40,000 Years of Aboriginal History, Lansdowne Press, Sydney.

James, W. \& Mills, D. (eds) (2005), The Qualities of Time: Anthropological Approaches, Berg, Oxford.

Johnson, D. (1998), Night skies of Aboriginal Australia, Oceania Monograph 47, University of Sydney, Sydney.

Jones, D. S., Mackay, S. \& Pisani, A. M. (1997), "Patterns in the valley of the Christmas Bush", Victorian Naturalist, vol. 114, no. 5, pp. 246-249.

Jones, R. M. (1985a), "From Xanadu to Kakadu: Interpretation of a Prehistory Pleasure Park", in Archaeological Research in Kakadu National Park. Special Publication no.13, R. M. Jones (ed.), Australian National Park \& Wildlife Service, Canberra, pp. 305-310.

Jones, R. M. (1985b), "Ordering the Landscape", in Seeing the First Australians, I. Donaldson \& T. Donaldson (eds), George Allen \& Unwin, Sydney, pp. 181-209. 
Jones, R. M. \& Meehan, B. (1997), "Balmarrk Wana: Big Winds of Arnhem Land", in Windows on Meteorology. Australian Perspective, E. K. Webb (ed.), CSIRO Publishing, Melbourne, pp. 14-19.

Kaberry, P. M. (1939), Aboriginal Woman: Sacred and Profane, Routledge, London.

Kalma, J. D. \& McAlpine, J. R. (1983), "Climate and Man in the Centre", in Man in the Centre, G. Crook (ed.), CSIRO Division of Groundwater Research, Perth, pp. 46-69.

Kilham, C., Pamulkan, M., Pootchemunka, J. \& Wolmby, T. (1986), Dictionary and Source-book of the Wki-Mungkan Language, Summer Institute of Linguistics, Darwin.

Kimber, R. G. (1997), "Cry of the Plover, Song of the Desert Rain”, in Windows on Meteorology. Australian Perspective, E. K. Webb (ed.), CSIRO Publishing, Melbourne, pp. 7-13.

Kolig, E. (1984 [1981]), “The Mobility of Aboriginal Religion”, in Religion in Aboriginal Australia: an Anthology, M. Charlesworth, H. Morphy, D. Bell \& K. Maddock (eds), University of Queensland Press, St Lucia, pp. 391-416.

Krappe, A. H. (1940), “The lunar frog”, Folklore, vol. 51, no.3, pp. 161-171.

Latz, P. (1995), Bushfires and Bushtucker. Aboriginal Plant Use in Central Australia, Institute of Aboriginal Development, Alice Springs.

Lauer, R. H. (1981), Temporal Man: the Meaning and Uses of Social Time, Praeger, New York.

Lawrence, R. (1968), Aboriginal Habitat and Economy, Geography Occasional Paper no. 6, Australian National University, Canberra.

Lewis, D. (1976), "Observations on route finding and spatial orientation among the Aboriginal people of the Western Desert region of Central Australia", Oceania, vol. 46, no.4, pp. 249-282.

Liberman, K. (1980), "The world-creative carpet snakes from the Australian desert", Folklore \& Mythology Studies, vol. 4, pp. 6-16.

Lourandos, H. (1997), Continent of Hunter-Gatherers. New Perspectives in Australian Prehistory, Cambridge University Press, Cambridge.

McCarthy, F. D. (1953), “Aboriginal rain-makers”, Weather, vol. 8, pp. 72-77.

McConnel, U. H. (1930), “The Wik-Munkan tribe of Cape York Peninsula”, Oceania, vol. 1, no. 1, pp. 97-104, 181-205.

MacPherson, P. (1881), "Astronomy of the Australian Aborigines", Journal and Proceedings of the Royal Society of New South Wales, vol. 15, pp. 71-80.

Massola, A. (1966), "The Aborigines of the Mallee", Proceedings of the Royal Society of Victoria, vol. 79, no. 2, pp. 267-274.

Mathews, R. H. (1904), "Ethnological Notes on the Aboriginal Tribes of New South Wales and Victoria", Journal of the Royal Society of New South Wales, vol. 38, pp. 203-381.

Memmott, P. (2007), Gunyah, Goondie + Wurley: The Aboriginal Architecture of Australia, University of Queensland Press, St Lucia, Queensland.

Merlan, F. (1998), Caging the Rainbow. Places, Politics, and Aborigines in a North Australian Town, University of Hawai'i Press, Honolulu.

Mountford, C. P. (1937), "Aboriginal crayon drawings. II. Relating to totemic places in southwestern Central Australia”, Transactions of the Royal Society of South Australia, vol. 61, pp. 226-240.

Mountford, C. P. (1956), Arnhem Land: Art, Myth and Symbolism. Records of the American-Australian Scientific Expedition to Arnhem Land, Vol 1, Melbourne University Press, Melbourne.

Mountford, C. P. (1965), Ayers Rock. Its People, Their Beliefs and Their Art, Angus \& Robertson, Sydney.

Mowaljarlai, D. \& Malnic, J. (1993), Yorro Yorro. Aboriginal Creation and the Renewal of Nature. Rock Paintings and Stories from the Australian Kimberley, Inner Traditions, Rochester, Vermont.

Mulvaney, D. J. \& Kamminga, J. (1999), Prehistory of Australia, Allen \& Unwin, Sydney.

Mutitjulu Community \& Baker, L. (1996), Mingkiri. A Natural History of Uluru by the Mutitjulu Community, Institute for Aboriginal Development Press, Alice Springs.

Myers, F. R. (1986), Pintupi Country, Pintupi Self, Sentiment, Place, and Politics Among Western Desert Aborigines, Australian Institute of Aboriginal Studies, Canberra. 
Nash, D. (1992), "Hot and Cold Over Clockwise", in The Language Game. Papers in Memory of Donald C. Laycock, T. E. Dutton, M. D. Ross \& D. T. Tryon (eds), Pacific Linguistics Series C110, Australian National University, Canberra, pp. 291-297.

Palmer, E. (1885), "Concerning some superstitions of North Queensland Aborigines", Proceedings of the Royal Society of Queensland, vol. 2, pp. 163-175.

Plomley, N. J. B. (1966), Friendly Mission. The Tasmanian Journals and Papers of George Augustus Robinson. 1829-1834, Tasmanian Historical Research Association, Hobart.

Plomley, N. J. B. (Brian) (1997), "Contacts with the Tasmanian Aborigines", in Windows on Meteorology. Australian Perspective, E. K. Webb (ed.), CSIRO Publishing, Melbourne, pp. 42-45.

Pyne, S. J. (1991), Burning Bush. A Fire History of Australia, Holt, New York.

Reid, A. (1995), Banksias and Bilbies: Seasons of Australia, Gould League, Melbourne.

Roberts, J., Fisher, C. J., Gibson, R. \& Popp, T. (1995), A Guide to Traditional Aboriginal Rainforest Plant Use by the Kuku Yalanji of the Mossman Gorge, Bamanga Bubu Ngadimunku, Mossman, Queensland.

Rose, D. B. (1987), "Consciousness and Responsibility in an Aboriginal Religion", in Traditional Aboriginal Society. A Reader, W. H. Edwards (ed.), Macmillan, Melbourne, pp. 257-269.

Rose, D. B. (1996), Nourishing Terrains: Australian Aboriginal Views of Landscape and Wilderness, Australian Heritage Commission, Canberra.

Rose, D. B. (1997), "When the Rainbow Walks", in Windows on Meteorology. Australian Perspective, E. K. Webb Ed.), CSIRO Publishing, Melbourne, pp. 1-6.

Rose, R. (1956), Living Magic. The Realities Underlying the Psychical Practices and Beliefs of Australian Aborigines, Rand McNally \& Company, New York.

Roth, W. E. (1897), Ethnological Studies Among the North-West-Central Queensland Aborigines, Queensland Government Printer, Brisbane.

Roth, W. E. (1903), Superstition, Magic, and Medicine, North Queensland Ethnography Bulletin No. 5, Department of Public Lands, Brisbane.

Schürmann, C. W. (1879), "The Aboriginal Tribes of Port Lincoln in South Australia, Their Mode of Life, Manners, Customs ...", in The Native Tribes of South Australia, J. D. Woods (ed.), Dehane, Adelaide, pp. 207-252.

Simpson, J. (1997), "Perception of Meteorology in Some Aboriginal Languages", in Windows on Meteorology. Australian Perspective, E. K. Webb (ed.), CSIRO Publishing, Melbourne, pp. 20-28.

Smith, C. (1880), The Booandik Tribe of South Australian Aborigines, South Australian Government Printer, Adelaide.

Smith, M. \& Kalotas, A. C. (1985), "Bardi plants: an annotated list of plants and their use by the Bardi Aborigines of Dampierland, in north-western Australia", Records of the Western Australian Museum, vol. 12, no. 3, pp. 317-359.

Smyth, R. Brough (1878), The Aborigines of Victoria, 2 vols, Victorian Government Printer, Melbourne.

Spencer, W. B. \& Gillen, F. J. (1899), The Native Tribes of Central Australia, Macmillan, London.

Stanbridge, W. E. (1857), "On the Astronomy and Mythology of the Aborigines of Victoria”, Philosophical Institute of Victoria, Transactions, vol. 2, pp. 137-140.

Stanner, W. E. H. (1953 [1979]), "The Dreaming”, in White Man Got No Dreaming, Australian National University Press, Canberra, pp. 23-40.

Stevenson, P. (1985), "Traditional Aboriginal resource management in the wet-dry tropics: Tiwi case study", Proceedings of the Ecological Society of Australia, vol. 13, pp. 309-315.

Stone, A. C. (1911), "Aborigines of Lake Boga”, Proceedings of the Royal Society of Victoria, vol. 23, pp. 433-468.

Strehlow, T. G. H. (1970), "Geography and the Totemic Landscape in Central Australia: A Functional Study", in Australian Aboriginal Anthropology, R. M. Berndt (ed.), Australian Institute of Aboriginal Studies \& University of Western Australia, Perth, pp. 92-140. 
Sutton, P. (1988a), "Dreamings", in Dreamings: The Art of Aboriginal Australia, P. Sutton (ed.), Penguin, Melbourne, pp. 13-32.

Sutton, P. (1988b), "Myth as History, History as Myth", in Being Black. Aboriginal Cultures in "Settled" Australia, I. Keen (ed.), Aboriginal Studies Press, Canberra, pp. 251-268.

Sutton, P. (in press), "The Logic of Wik Camping", in Archaeological Invisibility and Forgotten Knowledge, O. Grøn \& K. Hardy (eds), British Archaeological Reports, Oxford.

Sutton, P. \& Snow, M. (in press), "Iridescence", in Re-materializing Colour, D. Young (ed.), Sean Kingston, Oxford.

Swain, T. (1993), A Place for Strangers. Towards a History of Australian Aboriginal Being, Cambridge University Press, Cambridge.

Taplin, G. (1879), "The Narrinyeri", in The Native Tribes of South Australia, J. D. Woods (ed.), E. S. Wigg, Adelaide, pp. 1-156.

Taylor, L. (1996), Seeing the Inside. Bark Painting in Western Arnhem Land, Oxford University Press, Oxford.

Teichelmann, C. G. (1841), Aborigines of South Australia, Committee of the South Australian Wesleyan Methodist Auxiliary Society, Adelaide.

Teichelmann, C. G. \& Schürmann, C. W. (1840), Outlines of a Grammar ... of the Aboriginal Language of South Australia, 2 parts, Thomas \& Co., Adelaide.

Thomson, D. F. (1939), "The seasonal factor in human culture: illustrated from the life of a contemporary nomadic group", Prehistorical Society Proceedings, vol. 5, no. 2, pp. 209-221.

Thomson, D. F. (1949), Economic Structure and the Ceremonial Exchange Cycle in Arnhem Land, Macmillan, Melbourne.

Thomson, D. F. (1975), Bindibu Country, Nelson, Melbourne.

Tindale, N. B. (1933), Journal of an Anthropological Expedition to the Mann and Musgrave Ranges, North West of South Australia, May-July 1933, and a Personal Record of the Anthropological Expedition to Ernabella, Aug. 1933, AA 338/1/9, South Australian Museum Archives, Adelaide.

Tindale, N. B. (1935), Anthropological Expedition to Warburton Range, Western Australia. JulySeptember 1935 Journal, AA338/1/14, South Australian Museum Archives, Adelaide.

Tindale, N. B. (1957), Journal of Visit to the North West of South Australia and adjacent parts of Western Australia by Norman B. Tindale. April-May 1957, AA338/1/22/1, South Australian Museum Archives, Adelaide.

Tindale, N. B. (1959), "Totemic beliefs in the Western Desert of Australia - part 1: Women who became the Pleiades", Records of the South Australia Museum, vol. 13, no. 3, pp. 305-332.

Tindale, N. B. (1972), "The Pitjandjara”, in Hunters and Gatherers Today. A Socioeconomic Study of Eleven Such Cultures in the Twentieth Century, M. G. Bicchieri (ed.), Holt, Rinehart \& Winston, New York, pp. 217-268.

Tindale, N. B. (1974), Aboriginal Tribes of Australia: Their Terrain, Environmental Controls, Distribution, Limits, and Proper Names, Australian National University Press, Canberra.

Tindale, N. B. (1978), "Notes on a Few Australian Aboriginal Concepts" in Australian Aboriginal Concepts, L. R. Hiatt (ed.), Australian Institute of Aboriginal Studies, Canberra, pp. 156-163.

Tindale, N. B. (1981), "Desert Aborigines and the Southern Coastal Peoples: Some Comparisons", in Ecological Biogeography of Australia, A. Keast (ed.), Junk, The Hague, pp. 1855-1884.

Tindale, N. B. (1983), "Celestial Lore of Some Aboriginal Tribes", The First International Conference on Ethnoastronomy: Indigenous Astronomical \& Cosmological Traditions of the World, 5-9 September 1983, Smithsonian Institute, Washington, D.C., p. 20.

Tunbridge, D. (1988), Flinders Ranges Dreaming, Aboriginal Studies Press, Canberra.

Urry, J. \& Walsh, M. (1981), "The lost 'Macassar language' of Northern Australia”, Aboriginal History, vol. 5, no. 2, pp. 90-108.

Warner, W. L. (1937), A Black Civilization: A Study of an Australian Tribe, rev. edn, 1964, Harper Torchbook, New York.

Wilhelmi, J. F. C. (1861), "Manners and customs of the Australian Natives in particular of the Port Lincoln district", Transactions of the Royal Society of Victoria, vol. 5, pp. 164-203. 